\title{
Danmark har ingen Ruslandspolitik
}

\section{Mikkel Vedby Rasmussen}

\section{Danmark har mange strenge at spille på i forhold til Rusland, men det er vigtigt at finde melodien}

"Og hvad er så Danmarks reaktion på Ruslands invasion af Georgien?”, spurgte en amerikansk kollega mig for nogle uger siden.

Eftersom han var tæt knyttet til en af præsidentkandidaterne, og således havde fulgt debatten mellem McCain og Obama om, hvorledes man bedst forholder sig til Ruslands villighed til at bruge kampvogne og olie til at få sin vilje, og eftersom han havde registreret de skarpe svenske og norske reaktioner på den russiske handling, så var han overrasket over mit svar: "Ikke nogen".

Som jeg skyndte mig at forklare ham, så var det selvsagt en overdrivelse. Både udenrigs- og statsministeren fordømte den russiske brug af væbnet magt, og begge har i NATO og EU arbejdet for en samlet europæisk reaktion på Ruslands invasion. Men det var en overdrivelse, som fremmede forståelsen af, at selvom Ruslands invasion af Georgien er blevet taget alvorligt i Køben- havn, så er den ikke blevet betragtet som et alvorligt problem, der kræver en radikal nytænkning af dansk udenrigs- og sikkerhedspolitik.

Min amerikanske kollega havde grund til at være forundret. Hvis man tror på geopolitik, som han gør, så burde Danmark have reageret på den russiske invasion på nogenlunde samme måde som den norske og den svenske regering. Men et kort kan læses på mange måder. I både Norge og Sverige bekræftede den russiske invasion af Georgien en udbredt opfattelse af, at Rusland 20 år efter den Kolde Krigs afslutning stadig er en farlig nabo. I Sverige havde en forsvarskommission netop diskuteret, i hvor høj grad Sveriges sikkerhed var afgjort af truslen fra Rusland, og udgivelsen af beretningen blev udskudt for at tage højde for de nye begivenheder.

Når nordmændene i forvejen frygtede, hvad russerne var ude på i det høje nord, så bekræftede Georgiens 
skæbne blot de værste anelser. Anelser, som ikke var uden betydning $\mathrm{fx}$ for overvejelserne om, hvilket behov Norge har for nye kampfly. Når svenskere og nordmænd læste om Georgien i avisen, så læste de mellem linjerne en historie, som handlede om dem selv. I Danmark læste vi blot historier om et land langt borte, om hvilket vi - med Joseph Chamberlains ord - vidste lidet.

Et statsapparat fungerer ved at løse de problemer, som politikere og embedsmænd er enige om eksisterer, påpeger Henry Kissinger; et statsapparat fungerer ikke ved at påpege problemer eller løsninger, som ligger uden for denne konventionelle visdom.

I Norge og Sverige var Rusland i forvejen på den sikkerhedspolitiske dagsorden; og derfor blev begivenhederne i Georgien vigtige. I Danmark er Rusland ikke på dagsordenen; og derfor vakte Ruslands invasion ganske vist opmærksomhed, men den udløste ikke en selvransagelse blandt embedsmænd og politikere om, hvorvidt Danmark skulle revidere sin trusselsvurdering eller føre en anden politik.

\section{Tryghed uden fortilfælde}

Den konventionelle visdom siger, at Rusland spiller en forsvindende lille rolle i dansk sikkerhedspolitik.

Ved afslutningen af den Kolde Krig aflærte den sikkerhedspolitiske elite sig at fokusere på Rusland.
Hvor forholdet til Rusland havde været den definerende faktor i dansk sikkerhedspolitik under den Kolde Krig, var nu reduceret til et perifert emne. Det skete ikke umiddelbart efter murens fald. Tværtimod var det først med forsvarskommissionen af 1997, at den Kolde Krigs afslutning og Sovjetunionens sammenbrud blev fortolket ind i dansk sikkerhedspolitik. Kommissionen konkluderede: "Danmark i dag nyder godt af en sikkerhedsgeografisk placering, der indebærer tryghed nærmest uden fortilfælde. Det er endvidere kommissionens vurdering, at der ikke i de næste 10 år vil opstå en direkte konventionel militær trussel mod Danmarks sikkerhed."

Det var ikke nogen dristig konklusion i 1997, hvor Ruslands økonomi var på sammenbruddets rand, hvor de væbnede styrker mest blev brugt til at holde Moskvas decimerede besiddelser fast og oppositionen nede, og hvor Rusland for første gang siden 1917 havde en regering, som $\emptyset$ nskede at skabe et åbent samfund. Alligevel handlede kommissionens analyse meget mere om, hvad Rusland (ikke) kunne og ville, end om hvad de næste år ville bringe. Det var en analyse, som bortdefinerede et problem; den beskrev ikke med samme sikkerhed de nye udfordringer, som Danmark stod overfor. Det tog man først for alvor hul på i arbejdet med forsvarsforliget i 2004.

En af grundene til, at Ruslandsspørgsmålet skulle diskuteres så 
grundigt var, at truslen mod Danmarks territorium havde været den traditionelle begrundelse for at opretholde danske væbnede styrker. Alle tidligere forsvarskommissioner siden 1945 havde startet med at definere truslen fra øst og så designet et forsvar til at imødegå denne trussel. Hvis truslen var væk, hvad skulle et forsvar så nytte?

I stedet for Rusland og Warszawapagten blev internationale operationer i løbet af 1990'erne dimensionerende for dansk forsvar.

Våbensystemer, der som ubådene så udpræget tjente en Kold Krigs funktion, blev symbolsk ofret for at demonstrere, at forsvaret ikke handlede om Østersøen, men Østen. Forsvarspolitikken udfoldede sig i stadigt fjernere egne af verden, mens sikkerhedspolitikken i stigende grad handlede om at opbygge stabile institutioner - først i Europa med udvidelsen af NATO og EU, og siden gennem genopbygning i fejlslagne stater på Balkan og i Mellemøsten.

At åbne diskussionen om Rusland vil således være at åbne diskussionen om den måde dansk sikkerheds- og forsvarspolitik er blevet indrettet på de sidste 20 år. Hvis Danmarks 'sikkerhedsgeografiske situation' er blevet værre, end den var i 1997, skal værnepligten så genindføres, nye ubåde købes, og soldaterne lægge ørkenuniformen og trække i den grønne kamuflage? Skal udenrigsministeriets fokus flyttes fra Bruxelles og Kabul til Kiev og Moskva? De etablerede sandheder er ikke blot en analyse, det er også det system, som analysen har skabt. Hvis analysen ændrer sig, hvad skal der så ske med systemet og de mennesker, som skaber deres karriere i det? I dag hævner det sig, at man skabte en ny sikkerheds- og forsvarspolitik ved at definere den russiske trussel væk i stedet for at definere nye udfordringer. Hvis man i 1997 havde evnet at se Rusland som en del af en ny sikkerhedspolitisk virkelighed, så ville vi i dag ikke stå i en situation, hvor den historie, som der bliver fortalt om dansk sikkerhedspolitik, siger, at enten er Rusland ligegyldig eller også er landet en eksistentiel trussel.

Rusland er ikke en trussel mod Danmark og resten af den vestlige verden, som Rusland var det under den Kolde Krig. Den gang havde Rusland konkrete planer, om at føre krig mod Danmark og vores allierede - og Rusland havde midlerne til at føre den trussel ud i livet. Det er indlysende, at Rusland hverken har evnen eller viljen til at være en sådan trussel i dag. Siden spørgsmålet om, hvorvidt Rusland er en trussel eller ej, former den konventionelle visdom om Rusland i Danmark, så kan Ruslands handlinger over for Georgien affærdiges på linje med den seneste tids militærøvelser.

\section{Risikovurderingens betydning}

Det er korrekt, at Ruslands militære magt ikke er, hvad den har været. 
Men det forandrer ikke det faktum, at Rusland - som det eneste europæiske land - bruger militær magt over for sine naboer. Charles King konkluderer således i novembernummeret af Foreign Affairs, at "for fremtidige historikere vil krisen om Sydossetien markere det tidspunkt, hvor Rusland begyndte at ignorere de eksisterende internationale institutioner og begyndte at opbygge sine egne".

Det er ligeledes korrekt, at Rusland ikke ville kunne finde på at invadere Danmark som Georgien blev invaderet. Men det forandrer ikke det faktum, at Rusland har en aggressiv udenrigspolitik på andre områder. Ved at måle 'truslen fra Rusland' med den Kolde Krigs alen, overser man således den måde som Rusland og den sikkerhedspolitiske virkelighed har forandret sig.

Rusland er ikke en trussel, men Rusland udgør en risiko i en globaliseret verden. Hvor en trussel er konkret og målbar, så lader en risiko sig ikke måle og veje på samme måde som de russiske kampvogne og missiler under den Kolde Krig. En risiko er defineret af ens forventninger til, hvad risikoen kan føre med sig. At køre med den rutinerede chauffør Peter indebærer ikke den samme risiko som at køre med Henrik, der aldrig har kørt bil før. Det betyder ikke, at Henrik vil køre galt, men det betyder, at man forholder sig anderledes til ham - man låner ham ikke sin bil, man tager ikke et lift med ham, eller man søger at reducere de risici, som Henrik skaber, ved at tilbyde ham køreundervisning. Risikovurderingen former således ens handlinger.

Putin kører Ruslands udenrigspolitik på en måde, hvor brugen af militær magt blot bliver et element blandt mange. Rusland bruger energiforsyning til at sikre sig indflydelse i Øst- og Centraleuropa og sine olieindtægter til at købe sig en plads i markedsøkonomiernes kreds. Samtidig bruger Rusland sit diplomati og sit sæde i FN's sikkerhedsråd til at skabe en diplomatisk modvægt til Vesten. Disse eksempler er blot nogle af facetterne i en politik, der samler mange forskellige områder omkring et samlet mål: at genetablere Ruslands stormagtsstatus.

Rusland vil ikke blive en stormagt på den måde, som Sovjetunionen var det. For Rusland vil ikke true med at forme den internationale orden og det internationale økonomiske system i sit billede. Rusland vil spille med efter globaliseringens regler, men spille sine kort på en måde, hvor Rusland står stærkest. Vi risikerer således ikke krig med Rusland, men at Rusland vil søge at øve indflydelse på sine nære naboer som de baltiske lande, og de lidt fjernere naboer, som Danmark.

Hvor et militært forsvar var det korrekte svar til Sovjetunionen, er det ikke nødvendigt over for Putins Rusland. Vores forsvar skal grundlæggende præsentere Rusland for 
en overvældende afskrækkelse sammen med vores NATO-allierede. Men det er ikke her slaget skal stå. Siden Rusland er en risiko, snarere end en trussel, så handler det om at påvirke den russiske politik. Hvor en defensiv afskrækkelse var den korrekte politik over for Sovjetunionen, er et aktivt engagement den korrekte politik over for Putins Rusland. Vi skal med andre ord give Rusland den samme opmærksomhed, som vi giver den arabiske verden. Hvis regeringen kan have et 'arabisk initiativ', hvis formål er at skabe venner af det åbne samfund og venner af Danmark, i en region, som ikke altid er os venligt stemt, hvorfor har regeringen så ikke et 'russisk initiativ'? Hvis Danmark kan have en strategi over for Kina, som koordinerer hele centraladministrationens indsats over for det land, hvorfor kan vi så ikke have en 'Ruslandsstrategi'?

\section{Bud på en strategi}

En Ruslandsstrategi skal rumme mange elementer for at møde den russiske magt de mange steder, hvor den nu manifesterer sig. Den skal bygge på en koordineret indsats mellem hele den danske statsadministration, hvor mulige risici fra Rusland vurderes og mødes samlet. Det kan formentlig kun finde sted, hvis statsministeriet sætter sin vægt bag koordinationsarbejdet. Selve denne koordinerede strategiske indsats vil formentlig være vigtigere end enkelt- elementerne, fordi en koordineret indsats vil give Danmark mulige for at føre en aktiv politik over for Rusland; i stedet for blot som i dag at kunne reagere på Kremls handlinger. Imidlertid vil det være nødvendigt med en konkret indsats på en række områder - her følger nogle forslag.

Det er ikke nødvendigt på nuværende tidspunkt at indkøbe nyt materiel eller opstille de danske styrker på en anden måde. Indsatsen i Irak og Afghanistan har betydet, at de danske væbnede styrker er af en bedre kvalitet end noget, Sovjetunionen stod overfor under den Kolde Krig. Imidlertid kan det være nødvendigt at sende et signal til Rusland i det arktiske område, hvor en aggressiv russisk udenrigspolitik på sigt kan udfordre danske interesser. Grønland er ikke Georgien, men Putins regime er Putins regime - og derfor vil det være på sin plads at signalere, at grænsespørgsmål m.v. rent faktisk skal løses inden for rammerne af Illuliset-aftalen, hvor landene i området har lovet at løse deres konflikter med fredelige midler.

Danmark kan sende to strategiske signaler til Rusland. Vi kan indgå i et flådesamarbejde med Norge i det arktiske område, hvor en fælles dansk-norsk flådestyrke kan patruljere under NATO-mandat. Det ville ikke alene sende et signal til Rusland om, at de nordiske lande står sammen og ikke kan spilles ud mod hinanden, og det kunne fastholde 
NATO's opmærksomhed i området. Ligeledes for at sikre en fælles front og fælles ressourcer i området, kunne man realisere de tanker, som bl.a. chefen for Søværnets Operative Kommando (SOK), Niels Wang har lanceret om en fælles dansk-amerikansk-canadisk arktisk kommando i Thule.

I 1990'erne talte daværende præsident Bill Clinton om, hvordan han var allieret med de russiske reformkræfter. Implikationen var, at man kunne have sine reservationer over for regimet i Kreml, men man støttede helhjertet op bag dem, som ville skabe et liberalt samfund, der ville dele Vestens mål for en ny verdensorden. Siden har den russiske regering gjort sit bedste for at gøre udenlandske alliancer med det russiske civilsamfund så vanskelige som muligt, mens de vestlige regeringer har stillet sig tilfredse med primært at forholde sig til russiske ministre og milliardærer. Det er en fejl, som Danmark kunne være blandt de første til at rette. En måde kunne være at bring russere til Danmark for at uddanne dem i demokrati og demokratisk aktivisme. Med andre ord et program, som ville have meget tilfælles med det arabiske initiativ.

Samtidig skulle den danske regering aktivere danske virksomheder som store aktiver i Rusland. Man kalder ofte den nye generation af russere for ‘øl-generationen'; og når et dansk firma (Carlsberg) brygger meget af den $ø l$, som de unge russe- re drikker, så skal det bruges til at skabe et positivt billede af Danmark, så vi ikke kan blive dæmoniseret som georgierne.

\section{Beredskab i Danmark}

For at Danmark kan have en sammenhængende Ruslandspolitik, må der være et bredt kendskab til landet såvel som dets politik både i de kredse, hvor man diskuterer og formidler dansk udenrigspolitik, og dér hvor man fører den.

I lange tider har forsvarets sprogofficerer udgjort kernen i et sådant netværk, fordi de havde en forståelse for landet og et netværk med sig fra deres studier i russisk. Forsvaret har nu nedlagt uddannelsen, og hvis den ikke skal genopbygges, så skal andre overtage rollen at uddanne fremtidens Ruslands eksperter. Dem vil der også blive brug for i efterretningstjenesterne, der i de kommende år må fokusere på Rusland.

Danmark har mange andre strenge at spille på i forhold til Rusland, men det er vigtigt at vi finder melodien. Vi kan ikke længere nynne med på gamle slagere om Rusland som enten en dramatisk militær trussel eller en melankolsk fiasko af et land i Øst. Rusland er ved at finde en ny stormagtsrolle i en ny tid; og Danmark må finde en Ruslandspolitik, der passer til.

Mikkel Vedby Rasmussen, ph.d., chef for Dansk Institut for Militare Studier. 